During the hundred years of Survey work in Scotland, seventy-two memoirs on general and scientific geology, thirty-eight economic memoirs and thirty-six pamphlets on mineral resources, and nine pamphlets on underground water supply have been published. In the thirty years between 1910 and the outbreak of the last War, sixty-nine oneinch maps and ten quarter-inch maps were colourprinted. Sales stocks were destroyed during the Second World War ; but since 1945, in collaboration with the Ordnance Survey, every effort has been made to replace the lost maps, while continuing to publish new maps on the one-inch scale and many second revision coalfield maps on the six-inch scale.

As a result of growing recognition of the scope and national importance of the Geological Survey's work, increases of staff followed both World Wars. The most recent expansion is not yet complete enough to balance increased commitments. In Scotland, for example, extensive collaboration with the Scottish Division of the National Coal Board and with the North of Scotland Hydro-Electric Board, the annual incidence of some hundreds of inquiries from other government departments and the general public, and the work involved in republishing colour-printed maps destroyed by enemy action, have prevented the Survey from making rapid progress over the whole field of its activities. A. G. MACGREGor

\section{THE TRAINING OF UNIVERSITY TEACHERS}

$\mathrm{T}$ $\mathrm{HE}$ question of the advisability and possibility of providing new recruits to university teaching with some initial guidance in the technique of their calling has been examined by $\mathrm{S}$. Radcliffe, lecturer in German at the University of Bristol (Univ. Rev., 28, No. 1 ; October 1955).

Unlike France, little attention has been paid to the technique of lecturing in Great Britain. In general, lecturers are conscientious about the matter of their lectures, but give little thought to their form or their delivery.

That this can have a detrimental effect on students' work was borne out recently in the Vice-Chancellor's report for $1954-55$ to the Convocation of the University of Liverpool. In examining the causes of failure among students taking university examinations, he includes, among "matters about which our consciences ought to be troubled", the following point : "the presentation of a subject in the lecture room, though impeccable as regards content, does on occasion leave much to be desired in the matter of elementary teaching techniques".

This is the most vital point of all. The cause of so much dissatisfaction quite often proves to be some fault in the technique of presentation, or even a mere mechanical shortcoming, which could in most cases so easily have been circumvented by some initial instruction and guidance of the lecturer concerned.

Radcliffe does not claim that teaching is a mechanical craft to be learned in a workshop, but suggests that an artist requires some basic instruction, at least in the rudiments of his craft.

The following are a few of the purely mechanical skills which might be considered desirable in a good teacher or lecturer. First, the adoption of a fitting speed and clarity of diction. Secondly, the clear formulation and appropriate stressing of the main points of the subject under review. Thirdly, the ability to use a blackboard successfully. Fourthly, the 'staging' of material to make it come 'alive'. The correct lighting and ventilation of the lecture room are of importance. A few weeks teaching in any school will bring these and many allied points home.

What is a fitting speed and clarity of diction? How many lecturers ask their students whether they can hear clearly, or whether they are speaking too quickly for them? A teacher can soon learn the correct measure in these instances with the aid of a little guidance. The undue dropping of the voice at the end of each sentence, for example, can produce both monotony and inaudibility. A person with a weak voice can be shown how to make the most of it by someone trained in these matters. This is a problem faced by teacher-training departments.

The clear formulation and appropriate stressing of the main points of the subject cover a large number of factors. Just as the potential teacher must learn how to arrange and present the various points he is intending to convey in a lesson, so must the lecturer have a clear and systematically arranged plan of what he intends to talk about. He must know which points are important or difficult enough to require particular stressing, either in the form of repetition or slower and more deliberate speaking, or even by the dictation of vitally relevant matter.

The extent to which the blackboard is used will obviously vary with the nature of the lecture; a statistical, technical or linguistic theme will call for more blackboard writing than, say, a literature or philosophy lecture. Titles of works, proper-names, unusual or foreign terms, dates-all these should be written up to ensure that students get the correct form. The writing must be clear and legible, and not scattered about in disorder on the board.

Lastly, Radcliffe elucidates his reference to the proper 'staging' of material. There is an element of the histrionic in all personal teaching; the teacher is to some extent an actor, who must make his material come to life. There are some generally recognized devices into the application of which the tyro could with advantage be initiated. A slight break before passing on to a new theme in a lecture can be most refreshing for all concerned. An occasional pause to receive questions from students will in certain cases add to the effectiveness of the lecture; it "draws the students in" more and gives the lecturer a chance to gauge their grasp of what he is saying. Learning the students' names is an essential requirement in establishing such closer contact with them. The prompt return of written work not only helps to keep up students' interest in their subject, but also gives the right to demand written work from the students within the time-limit specified.

\section{MORPHOGENETIC STUDIES OF DRYOPTERIS}

$\mathrm{N}$ two studies, the growth, organization and 1 morphogenetic activity of the shoot apex of Dryopteris aristata have been further investigated by experimental means. C. W. Wardlaw and E. G. Cutter (Ann. Bot., 19, 76, 515; 1955) have observed that when the apical cell-group is damaged, leaf 
primordia, which may be orientated abnormally, continue to be formed on the meristem ; but one or more buds may also arise. The observations reported here indicate that a zone at the periphery of the apical meristem is particularly reactive when the apical cell group is damaged, the majority of buds being induced in this region. The extent of damage to the apex may affect the sequence of organogenesis : when damage is extensive buds tend to be formed immediately, subsequent primordia developing as leaves; when the damage is confined to the apical cell, or extends to only a few of its segments, bud formation tends to be delayed. It is concluded that the effect of the apical cell on organ formation is exercised through the growth and organization of the apex as a whole.

E. G. Cutter (ibid., 485) has also observed that in the shoot apex in Dryopteris aristata, maintained under conditions of progressive starvation for periods up to a year, the apex decreases very markedly in size; the size of leaf primordia at their inception decreases, but their size relative to the shoot apex increases; the rate of inception of leaf primordia decreases; the rate of morphological development of leaf primordia increases; there is a reduction in the system of phyllotaxis towards that characteristic of sporelings; the vascular system of the attenuated axes is dictyostelic, but there is a reduction in the number of meristeles in the axis and in the leaves.

\section{THE SCIENTIFIC CIVIL SERVICE PROMOTION OF INDIVIDUAL RESEARCH WORKERS}

CPECIAL posts have been created in the Scientific Civil Service, as in previous years, under provisions included in the White Paper (Cmd. 6679: 1945), designed to provide for the promotion of individual research workers of exceptional merit. The promotions_are effective from July 1, 1955.

\section{Chief Scientific Officer}

Dr. P. B. Walker spent five years as a designer in the aircraft industry after postgraduate research in the University of Cambridge on fluid motion. Then in 1935 he joined the Royal Aircraft Establishment, Farnborough, and was a pioneer of the rational scientific approach to aircraft structural design in place of the old empirical formulæ. During the Second World War he was responsible at the Ministry of Aircraft Production for the supervision of the design of gliders and paratroop aircraft. Dr. Walker returned to the Establishment in 1945 as head of the Structures Department, where he concentrated on building up first the Flutter Division, and secondly the Aircraft Structural Fatigue Division, into flourish. ing teams with widespread reputations. In particular, his work on aircraft fatigue was of great importance in connexion with the investigation of the Comet aircraft, for which he was made C.B.E. In 1951 he delivered the Wright Brothers Lecture in Washington, D.C.

\section{Deputy Chief Scientific Officers}

Mr. E. H. Cooke-Yarborough entered government service in 1940 and worked on the development of airborne radar. Later he concentrated on radio counter-measures and also on guided weapons. In 1946 he bocame interested in atomic energy, and eventually joined the Atomic Energy Research Establishment, Harwell, where he is at present. deputy head of the Electronics Division. Mr. CookeYarborough is well known as a specialist in the design of electronic circuits, and during recent years he has been associated with the design of digital computers and the use of transistors; a new cornputer employing transistors as circuit components is now in use at Harwell.

Mr. B. Sykes joined the Royal Aircraft Establishment, Farnborough, in 1925 from the Imperial College of Science and Technology, London, and his early work was in the field of aircraft electrical engineering, covering such problems as electrically heated flying clothing and the design of a selfregulating generator for aircraft. During the Second World War he played a considerable part in the design and setting up for production of predictor gunsights, and since the War he has been increasingly concerned with general problems of air fighting.

Dr. P. C. Thonemann graduated from the University of Melbourne in 194.0 and worked first at the Munition Supply Laboratories, Victoria, and then at the Research Laboratories of Amalgamated Wireless of Australasia, where he was concerned with propa. gation problems. Later he gained a Commonwealth research followship at the University of Sydney, studying physical phenomena in ionized gases, and assisted in the development of gas-discharge modulator switches. At the Clarendon Laboratory, Oxford, he continued to study gas-discharge phenomena and their applications in nuclear science, and this led to the production of the radio-frequency type of proton source which is now used almost universally in laboratories equipped with high-voltage sets for the acceleration of ion beams. Since 1949 he has directed the work of a group investigating the properties of highly ionized gases.

Dr. D. Williams entered the Royal Aircraft Establishment, Farnborough, in 1924 from industry, where he had served as a pupil apprentice after graduating in mechanical engineering from University College, Cardiff, in 1922. Following a fow years on stress calculations and the supervision of experimental aircraft contracts, he began work in 1930 on aeronautical structural research. During recent years his research has covered a wide field, including the first complete mathematical theory of 'sandwich' construction, the response of aeroplane structures to dynamic loading, aero-elastic calculations, pressurecabin problems, and the dynamic instability of systems incorporating pneumatic-tyred wheels.

\section{Senior Principal Scientific Officers}

Mr. G. K. Adams graduated in chemistry from the University of Bristol in 1942 and then joined the Armament Research Department of the Ministry of Supply, where until the end of the Second World War he worked on the thermal decomposition of explosives and the evaluation and combustion of pyrotechnic compositions. In 1946 he joined the Explosives Research and Development Establishment, where he has carried out theoretical and experimental researches on combustion processes, especially on rates of flame propagation and of chemical reactions in flames. 